\title{
The first record of a rare species of myxomycetes Perichaena heterospinispora in Asia
}

\author{
Anastasia Vlasenko $^{1^{*}}$, Dondov Budsuren ${ }^{2}$,Enkhtuya Ochirbat ${ }^{3}$, and Javkhlan Samiya ${ }^{3}$ \\ ${ }^{1}$ Central Siberian Botanical Garden SB RAS, 630090 Zolotodolinskaya st., 101, Novosibirsk, Russia \\ ${ }^{2}$ Plant Protection Research Institute of Mongolia, 17024, Khoroo 11, Khan-Uul district, Ulaanbaatar, \\ Mongolia \\ ${ }^{3}$ Botanical garden and research institute MAS, 13330, Peace Avenue-54b, Bayanzurkh district, \\ Ulaanbaatar, Mongolia
}

\begin{abstract}
In Mongolia, for the first time in Asia, a rare species of myxomycetes, Perichaena heterospinispora, has been recorded. Studies were conducted in the vicinity of Ulaanbaatar, in the steppes near Chinggis Khaan Airport. The article provides a description of this species, photographs of sporocarps, photographs of spores on a scanning electron microscope. A description and photographs of capillitial threads are presented for the first time. This rare species differs from all known species of the genus in its unique ornamentation of spores.
\end{abstract}

\section{Introduction}

Myxomycetes are free-living amoeboid plasmodial protists. Currently, about 1000 species have been identified in the world, united in 5 orders, 15 families and 64 genera. Myxomycetes are found in all terrestrial biomes where there are living plants or dead plant debris. In forests, myxomycetes live on tree debris (stumps, dead trunks, branches), mosses, lichens, old fruiting bodies of aphyllophoroid fungi, in leaf litter and soil [1]. In the steppes and deserts, due to the lack of other types of substrate, myxomycetes live in the litter, on the stems of perennial shrubs and weathered dung of herbivorous animals. Mostly in the mountains, cryotolerant nival species live, capable of forming sporophores next to melting snow. A special group of myxomycetes in all biocenoses is composed of epiphytic species that inhabit living plants.

In Russia, a little less than 500 species of myxomycetes are currently recorded, while in Mongolia only 44 species are known [2,3]. In 2019, we began the study of myxomycetes of Mongolia. Using the "moist chambers" method, we have recorded a new species of myxomycetes Perichaena heterospinispora Novozh., Zeml., Schnittler et S.L. Stephenson. The genus Perichaena was described E. M. Fries in 1817. Sporocarps are mainly sessile sporangia or plasmodiocarp, in some cases, sporangia with stalk. The peridium is double, the outer layer is granular and brittle, often covered with the deposition of calcium oxalate

* Corresponding author: anastasiamix81@mail.ru 
crystals, internal, membranous. Capillitium consists of hollow tubes, branched, with spikes or warts, sometimes capillitium is absent. Spores are yellow in mass, sometimes reddishbrown [4].

Currently, the genus Perichaena includes 36 species. Members of the genus are found on all continents except Antarctica. Prior to our research, 7 species of the genus Perichaena were reported in Mongolia: P. chrysosperma (Curr.) Lister, P. corticalis (Batsch) Rostaf., P. depressa Lib., P. liceoides Rostaf., P. luteola (Kowalski) Gilert, P. quadrata T. Macbr., $P$. vermicularis (Schwein.) Rostaf.

\section{Materials and methods}

The "moist chambers" method in the Petri dishes is based on the presence of resting stages in the life cycle of myxomycetes (microcysts, sclerotia), of which, under favorable conditions, plasmodia and then sporocarp can develop. Currently, this method is used worldwide to detect myxomycetes in steppe and desert communities [1].

The substrates for the experiments with "moist chambers" were collected 02.10 .19 , in the steppe communities near Ulaanbaatar, southeast of Chinggis Khaan Airport (Mongolia), $\mathrm{N} 47^{\circ} 49.545, \mathrm{E} 106^{\circ} 47.390,1350 \mathrm{~m}$. Each sample of the substrate (approximately 25 grams) was placed in a separate paper bag, indicating the serial number, type of substrate, date of collection and coordinates on the packet. The experiments with "moist chambers" were started on November 6, 2019.

Species identification was carried out using a Carl Zeiss EVO MA 10 scanning electron microscope, a Stemi DV4 stereo microscope, Axiolab Ere and Zeiss Axio Imager A1 light microscopes (Carl Zeiss Microscopy, Germany) in CSBG SB RAS. Specimens were prepared for scanning electron microscopy using traditional SEM techniques, summarized as follows. For microscopy, sporocarps were preserved as permanent slides in polyvinyl lactophenol. The nomenclature of myxomycetes follows Lado [5].

\section{Results and Discussions}

About 100 sporocarp of Perichaena heterospinispora NSK 103147 were found in one wet chamber on live rosettes of Goniolimon sp. on the 70th day of cultivation (figs. 1. a-d).

Perichaena heterospinispora, which we recorded in Mongolia, is morphologically identical to the description of the type specimen for this species, except that for the first time we found capillitial threads in this species.

The following is a diagnosis of the species.

Sporocarps are scattered, sessile or on a stalk, $0.6-0.8 \mathrm{~mm}$ in total height. Sporotheca rounded, $0.2-0.4 \mathrm{~mm}$ in diam., light yellow or olive brown, red-brown in the lower part, iridescent. Peridium membranous, thin, smooth, transparent, thicker in the lower part of the sporotica; dehiscence is irregular, the basal part remains in the form of a calyx, which makes up to $15 \%$ of the total height of the spotheca, with smooth edges. The stem is wrinkled, it is a continuation of the hypothallus. Hypothallus is conspicuous, welldeveloped, light yellow, membranous. Columella are absent. Capillitium is poorly developed, there are single thin tubes, 1-2 $\mu \mathrm{m}$ in diam., ornamented with large warts, sometimes almost smooth. The spore mass is yellowish-brown or cinnamon-brown. Spores are free, globose, ochre-yellow in transmitted light, (10.5-)12.0-13.5(-14.5) $\mu \mathrm{m}$ in diam., the spore surface has a complex ornamentation consisting of scattered large pyramidal spines $0.9-1.2 \mathrm{~mm}$ high, sometimes having enlarged ends, the surface of the spore among the large spines is covered with small, evenly and densely distributed warts, which are visible only with SEM. 

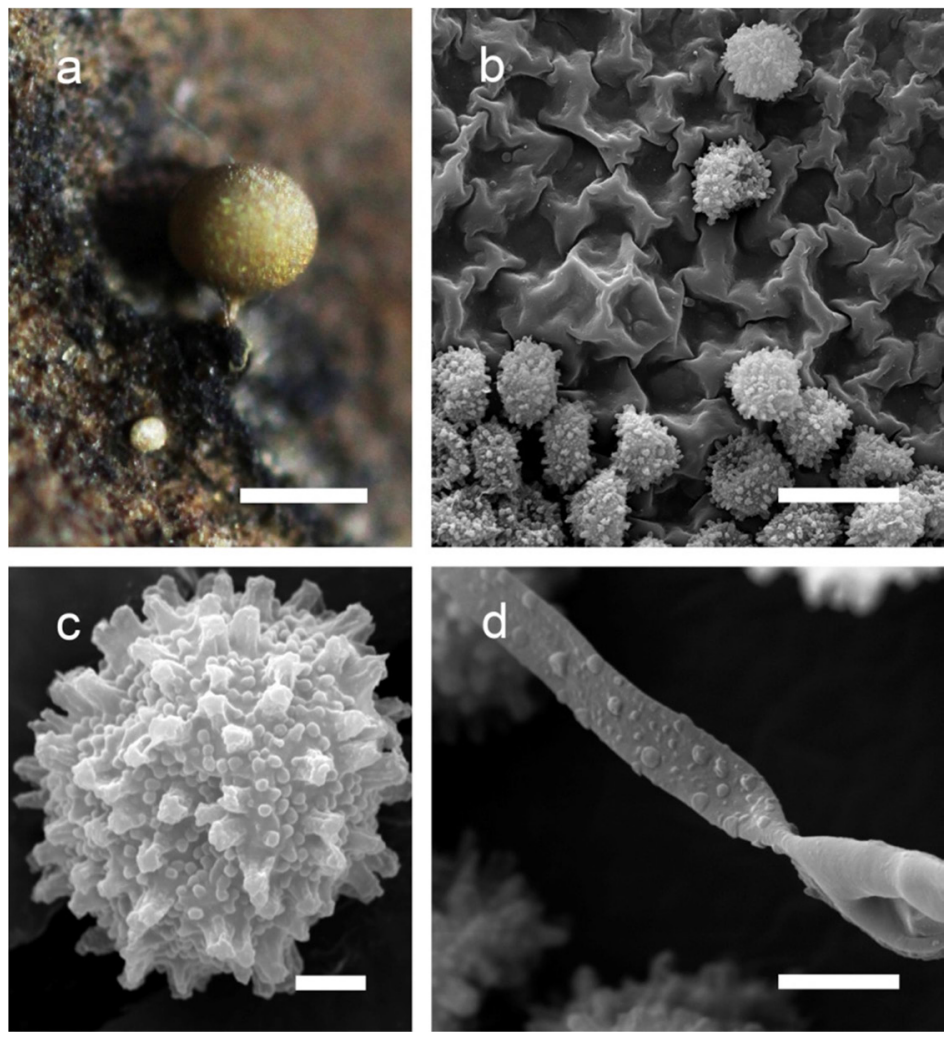

Fig. 1. Perichaena heterospinispora NSK 103147: A: sporangium. B: peridium and spores (SEM). C: spore (SEM). D: capillitium (SEM). Bars: A: $0.5 \mathrm{~mm}$. B: $20 \mu \mathrm{m}$. C, D: $2 \mu \mathrm{m}$.

\section{Conclusions}

The species Perichaena heterospinispora was described in 2008 from the southwestern part of Russia [6]. In 2016, the species is included in the Red Book of the Volgograd Region. Previously, this very rare species was known only from the Volgograd region (Russia), where it was recorded using the "moist chambers" method on fallen leaves and dead branches of shrubs and trees collected in petrophytic steppes and in a birch forest.

We found this species also using the "moist chambers" method, but on live Goniolimon sp. P. heterospinispora is probably an obligate litter species whose plasmodium crawled out of the litter onto rosettes in search of a moisture gradient. Earlier, in the Asian part of Russia, we recorded a rare coprobiont species Trichia brunnea J.J. Cox also on an atypical substrate for this species - fallen leaves of Rumex sp. [7]. Our studies have expanded our understanding of the substrate specialization of rare species of Perichaena heterospinispora and Trichia brunnea.

The work was funded by RFBR and MCESSM according to the research project 19-54-44002 Mong_T. Herbarium specimens from MG Popov Herbarium (NSK), Novosibirsk, were used.

\section{References}

1. Yu. K. Novozhilov, A. W. Rollins, M. Schnittler. Myxomycetes: Biology, Systematics, Biogeography and Ecology (2017) 
2. Yu. K. Novozhilov, O. G. Golubeva. Micologia i fitopatologia, 20, 368-374 (1986) (in Russian)

3. Yu. K. Novozhilov, M. Schnittler. Fungal diversity, 30, 97-119 (2008)

4. B. Ing. The Myxomycetes of Britain and Ireland: An Identification Handbook (1999)

5. C. Lado. An online nomenclatural information system of Eumycetozoa. Real Jardín Botánico, CSIC. Madrid, Spain. Available from: http://www.nomen.eumycetozoa.com. Accessed 2020 May 05 (2005-2020)

6. Yu. K. Novozhilov, I. V. Zemlyanskaya, M. Schnittler, S. L. Stephenson. Mycologia, 100, 816-822 (2008)

7. A. V. Vlasenko, Yu. K. Novozhilov, V. A. Vlasenko, A. Yu. Korolyuk, N. A. Dulepova. Izvestiya Irkutskogo gosudarstvennogo universiteta. Seriya Biologiya. Ecologiya, 21, 50-60 (2017) (in Russian) 